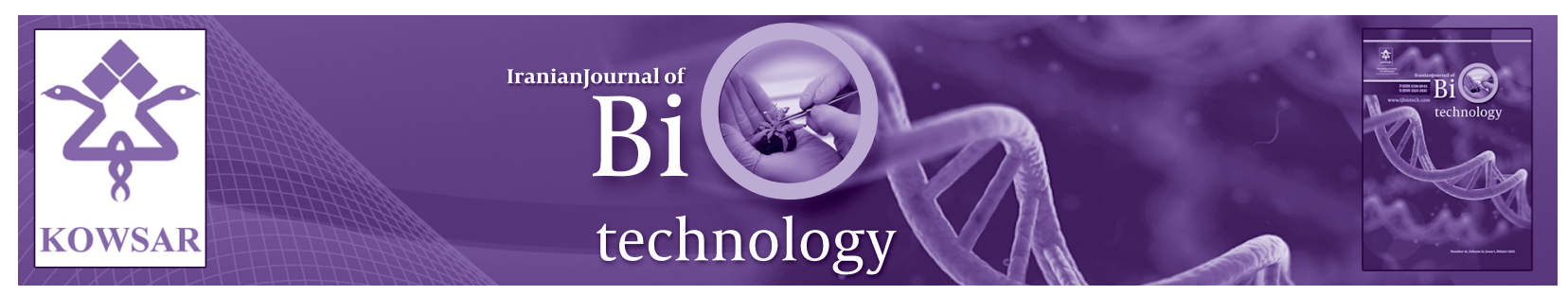

\title{
Codon Optimization, Cloning and Expression of the Human Leukemia Inhibitory Factor ( $h$ LIF) in E. coli
}

\author{
Parichehr Darabi ${ }^{1}$, Hamid Galehdari ${ }^{{ }^{*}}$, Saeed Reza Khatami ${ }^{1}$, Nahid Shahbazian ${ }^{2}$, Moham- \\ mad Shafeei ${ }^{1}$, Amir Jalali ${ }^{3}$, Ali Khodadadi ${ }^{4}$ \\ ${ }^{1}$ Department of Genetics, Shahid Chamran University, Ahvaz, IR Iran \\ ${ }^{2}$ Department of Gynecology, Ahvaz Jundishapur University of medical School, Ahvaz, IR Iran \\ ${ }^{3}$ Research Center of Toxicology, Ahvaz Jundishapur University of Medical School, Ahvaz, IR Iran \\ ${ }^{4}$ Cancer Research Center, Ahvaz Jundishapur University of Medical School, Ahvaz, IR Iran
}

\begin{tabular}{l}
\hline A R T I C L E I N F O \\
\hline Article type: \\
Research Article \\
\hline Article history: \\
Received: 09 Dec 2011 \\
Revised: 01 Aug 2012 \\
Accepted: 20 Nov 2012 \\
\hline Keywords: \\
Escherichia coli \\
Inhibitor Factor \\
pET-28a(+) \\
Recombinant Human Leukemia
\end{tabular}

\begin{abstract}
A B S T R A C T
Background: Leukemia inhibitor factor (LIF) is a very important pleiotropic cytokine which belongs to interleukin-6 (IL-6) family. LIF exerts multiple effects on different types of cells and tissues with numerous regulatory effects in vivo and in vitro. It is a lymphoid factor, which performs a number of activities including cholinergic neuron differentiation, control of stem cell pluripotency, bone and fat metabolism, and is important for embryo implantation and promoting megakaryocytes production in vivo. Human LIF is a potential therapeutic candidate for some diseases such as multiplesclerosis (MS). Objectives: Because of aforementioned applications of the LIF protein in biological systems, the LIF gene has been cloned in various species. In this study a useful novel method was used to clone an optimized LIF sequence.

Materials and Methods: In this study, the optimized cDNA form of human leukemia inhibitory factorwas cloned into the pET-28a (+) expression vector under control of T7lacpromoter using BamHI and XbaI restriction enzymes. The recombinant vector was transformed into Escherichia coli strain BL21(DE3). The cloned $h$ LIF cDNA was expressed as a fusion protein with His-tag. Cloning of $h$ LIF cDNA was confirmed by digestion and DNA sequencing. Appropriate expression of recombinant hLIF was examined by SDS-PAGE after induction with isopropylthio- $\beta$-galactoside (IPTG).

Results: The results confirmed the expression of the $19.7 \mathrm{kDa}$ rhLIF protein in the bacterial expression system.

Conclusions: We could show that codon optimization might increase the production of recombinant hLIF in the E. coli. This result is useful in similar cases, in which the level of expressed gene is critical. Published by Kowsar Corp, 2012. cc 3.0.
\end{abstract}

- Implication for health policy/practice/research/medical education:

Recombinant protein production and related studies.

- Please cite this paper as:

Darabi P, Galehdari H, Khatami SR, ShahbazianN, ShafeeiM, JalaliA, Khodadadi A. Codon Optimization, Cloning and Expression of the Human Leukemia Inhibitory Factor (hLIF) in E. coli. Iran J Biotech. 2013: 11(1): 47-53. DOI: 10.5812/ijb.9229

\footnotetext{
* Corresponding author: Hamid Galehdari, Department of Genetics, Shahid Chamran University, Ahvaz, IR Iran, Tel/Fax: +98-6113338965, E-mail: galehdari@scu. ac.ir
}

DOI: $10.5812 /$ ijb.9229

Copyright (c) 2013, National Institute of Genetic Engineering and Biotechnology; Published by Kowsar Corp.

This is an Open Access article distributed under the terms of the Creative Commons Attribution License (http://creativecommons.org/licenses/by/3.0), which permits unrestricted use, distribution, and reproduction in any medium, provided the original work is properly cited. 


\section{Background}

Leukemia inhibitory factor (LIF) is a pleiotropic cytokine which was firstly isolated from fibroblasts and is characterized by its ability to induce the differentiation of mouse myeloid leukemic M1 cells into macrophages (1). The LIF protein is a member of interleukin-6 (IL-6) subfamily (2). The interleukin-6 subfamily is a group of hematopoietic cytokines with a wide range of physiological functions in diverse fields, such as inflammation, immune responses, and cell survival including LIF, IL-6, IL-11, Ciliary Neurotrophic factor (CNTF), Cardiotrophin-1 (CT-1), Oncostatin M (OSM), and cardiotrophin-1. Two new Members were recently added to this family, which have been called as IL-27 and IL-3 $(3,4)$. These cytokines have some overlapping biological activities acting through receptors that share a common signaling molecule; the glycoprotein 130 (gp130) subunit $(1,5)$. The receptor for LIF protein is a heteromeric complex consisting of gp130 (also named LIFR $\alpha$ ) and the LIF receptor (LIFR, also referred as to LIFR $\beta$ ) (6). Expression of the LIFR $\beta$ determines cells responding to the LIF, due to ubiquitously expression of the gp 130 (7). LIF receptors are expressed on hemopoietic cells (macrophages and megakaryocytes), hepatocytes, osteoblasts, preadipocytes, embryonic stem cells, myoblasts, and neuronal cells (8-11). The Tyrosine kinase Janus kinas (JAK) binds constitutively to the intercellular domain of the LIF receptor complex in its inactive form. Upon LIF binding, JAK kinase phosphorylates tyrosine residues of both gp 130 and LIFR. This Phosphorylation recruits signal transducers and activators of transcription (STAT) 1 and STAT3 through their SH2 domains. STAT proteins are then activated by JAK-mediated tyrosine phosphorylation to form homodimers and/or heterodimers and are translocated in to the nucleus, where they function as transcription factors (Figure 1) (12, 13). LIF has various biological functions in many adult and embryonic tissues. In vitro biological effects of LIF vary depending on the cell type, for example LIF stimulates differentiation in M1 cells and inhibits differentiation in embryonic stem cells (14), increases the motility and survival rate of sperm (15). In vivo studies in mice have shown that LIF produces a 2 -fold increase in bone marrow megakaryocytes with a dose-dependent increase in platelet numbers (16). Increased platelet levels have also been observed in primates (17). The action of LIF on nerve cells has also been examined in animal models. Direct application of LIF to sites of nerve transaction improved survival of both sensory and motor neurons $(18,19)$. Nerve transection has been shown to increase expression of LIF and IL6 , and is associated with retrograde axonal transport of LIF (20). LIF has also been shown to retard progression of motor neuron disease in a murine model of this disorder (21). The human Lif has some other known functions like induction of acute phase proteins $(22,23)$ and is important in the embryo development (24-26).

\section{Objectives}

In this study a useful novel method was used to clone an optimized LIF sequence.

\section{Materials and Methods}

\subsection{Constructing expression vector of Pet-28a (+)-hLIF}

The hLIF gene encodes a 181 amino acid polypeptide chain (accession No. MN002309.3) which was optimized for fully expression in E. coli. Genetic codons of amino acids coded by more than one codon were changed to synonymous codons commonly used by E. coli (27). The optimized sequence was chemically synthesized and inserted in to the expression vector pET- 28a (+) with BamHI and XbaI restriction sites (Generay Biotech Co., Ltd). The pET$28 \mathrm{a}(+)$ introduces kanamycin resistance in drug sensitive host with the T7lac promoter for stable transcription. The 6x His-tag sequence is generated in the N-terminal to facilitate the purification step of the recombinant protein and a thrombin cleavage site for removing the His-Tag sequence from recombinant $h L I F$ after purification.

\subsection{Preparation of Competent Cells}

In this study, the competent E. coli BL21 (DE3) host cells were prepared with Calcium Chloride (28).

\subsection{Transformation of Recombinant Vector in to E. coli}

$100 \mu \mathrm{L}$ of competent cells was transferred in to a sterile and chilled tube. Then 20, 30, 40, $50 \mathrm{ng} . \mu \mathrm{L}^{-1}$ of recombinant vector was added to each tube, mixed the content of tubes by swirling gently and stored each tube on ice for $30 \mathrm{~min}$. Tubes were transferred in to heating block and heated at $42^{\circ} \mathrm{C}$ for 90 seconds. The tubes were rapidly transferred to ice for $2 \mathrm{~min}$. Then, $1 \mathrm{~mL} \mathrm{SOC}$ medium (Merck and HIMEDIA) was added to each tube and incubated for 1 hour in shaker incubator at $37^{\circ} \mathrm{C}$ to allow the bacteria recover and to express the kanamycin resistance marker encoded by the plasmid. After incubation, the tubes were centrifuged for $7 \mathrm{~min}$ and $9000 \mathrm{rpm}$ at $4^{\circ} \mathrm{C}$, then $1000 \mathrm{~mL}$ of supernatant was discarded and the rest was cultured in Lauria Bertaini (LB) medium (Merck and HIMEDIA) containing $40 \mu \mathrm{g} \cdot \mathrm{mL}^{-1}$ kanamycin. The plates were incubated for 12 to $16 \mathrm{~h}$ at $37^{\circ} \mathrm{C}(28)$.

\subsection{Confirming the Accuracy of Transformation}

The accuracy of transformation was verified by sequencing and double digestion of plasmid with BamHI and XbaI (Fermentas) enzymes.

\subsection{Induction of T7 Promoter}

The T7lac promoter is an inducible promoter which is induced with IPTG. Two percent of overnight pre culture was inoculated to a fresh LB medium containing kanamycin $\left(40 \mu \mathrm{g} \cdot \mathrm{mL}^{-1}\right)$ and incubated at $37^{\circ} \mathrm{C}$ until reaching the 
optimized optic density. The inducer IPTG (Fermentas) was added to the medium with two different final concentrations of 1 and $1.5 \mathrm{mM} \cdot \mathrm{mL}^{-1}$, and incubation was performed at $37^{\circ} \mathrm{C}$ for $14 \mathrm{~h}(28)$. The bacteria were harvested with a two $\mathrm{h}$ interval at $22^{\circ} \mathrm{C}$ and $28^{\circ} \mathrm{C}$, respectively. The bacteria cell pellets were suspended in $10 \mathrm{x}$ SDS-PAGE sample buffer (10g SDS, Cinagen; $30.3 \mathrm{~g}$ Tris and $144.1 \mathrm{~g}$ glycin; Merck), dissolved (in $800 \mathrm{~mL}$ deionized $\mathrm{H}_{2} \mathrm{O}$ and adjusted volume to 1 liter with $\mathrm{dH}_{2} \mathrm{O}$ ) and heated for 3 $\min$ at $85^{\circ} \mathrm{C}$. The samples were saved for protein expression analysis by SDS-PAGE.

\subsection{Analysis of Protein Expression}

Expression of the hLIF was evaluated by SDS-PAGE and Western blotting. The prepared samples and protein molecular weight marker (Fermentas) was heated at $95^{\circ} \mathrm{C}$ for $5 \mathrm{~min}$. Afterward each sample and marker was loaded on the $12 \%$ SDS-PAGE gel and run on the constant voltage of $100 \mathrm{~V}$ for $3 \mathrm{~h}$. The gel was stained with Coomasie brilliant blue R-250 (Sigma) for $2 \mathrm{~h}$ and destained with the solution containing $450 \mathrm{~mL}$ methanol, $100 \mathrm{~mL}$ acetic acid (Merck) and $\mathrm{H}_{2} \mathrm{O}$. Fractionated proteins by SDS-PAGE were also transferred to the PVDF membrane (Millipore) by Electro elution at $60 \mathrm{~V}$ for $3 \mathrm{~h}$. The PVDF membrane was incubated overnight in blocking buffer $(5 \% \mathrm{w} / \mathrm{v}$ skim milk (Merck) in $0.05 \% \mathrm{v} / \mathrm{v}$ PBS-Tween-20 solution) at $4^{\circ} \mathrm{C}$, followed by washing 3 times with PBS-Tween-20 and shaking in $50 \mathrm{rpm}$ for an hour in 1:200 dilution of mouse monoclonal LIF antibody (Santa Cruz biotechnology, Inc.), with repeating washing step 3 times with PBS-Tween 20. The membrane was then incubated with 1/2000 dilution of a goat anti-mouse IgG peroxidase conjugate (Sigma) and the signal was detected by 4-chloro-1-naphthol (Biogen, Iran) substrate solution.

\section{Results}

The synthetic human LIF cDNA was designed based on a published sequence. This synthetic gene was constructed from $555 \mathrm{bp}$ which is limited between the BamHI and the XbaI restriction sites. High level of expression was achieved by insertion of hLIF cDNA immediately downstream of the T7lac promoter (Figure 1). The BL21 (DE3) strain of the E. coli was transformed with the recombinant plasmid. After 12 to $16 \mathrm{~h}$ incubation of transformed bacteria, colonies were observed.

After extraction of transformed plasmid, a double digestion was performed which verified the accuracy of transformation (Figure 2). The correct nucleotide sequences of the synthetic $h L I F$ insert was verified by DNA sequencing using a universal 77 promoter primer (Figure 3).

The sequencing result from cloned recombinant LIF was blast (www.NCBI.org) and showing 79\% identity with the native human LIF (Figure 4). To determine the time of maximum expression level, SDS-PAGE analysis of the recombinant protein was performed. Two cultures were

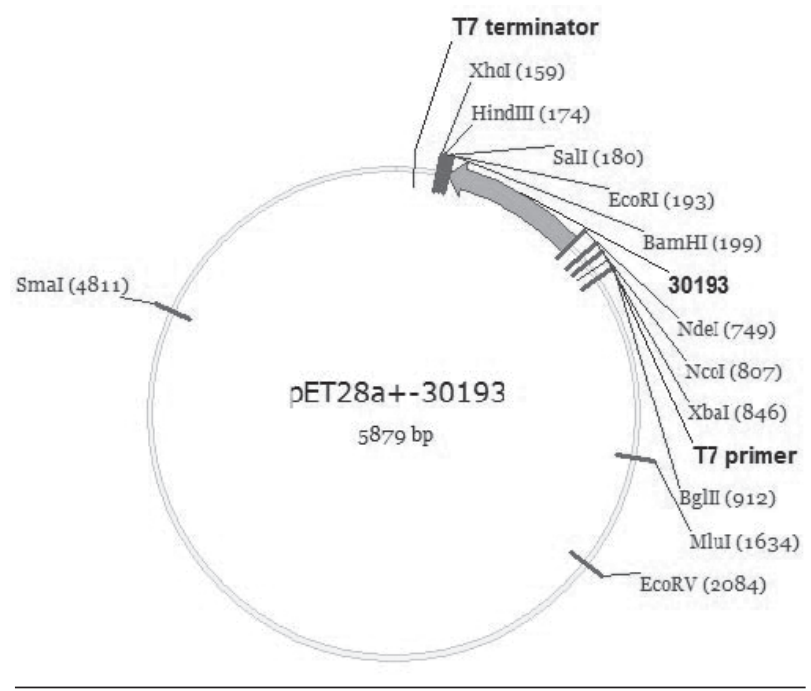

Figure 1. A Schematic Figure for Recombinant Vector and Inserting Sites

Figure 2. Left Image Indicates Single Digestion of the Recombinant Vector and Right Image Shows Double Digestion to Confirm the Existence of the Insert with the Appropriate Size

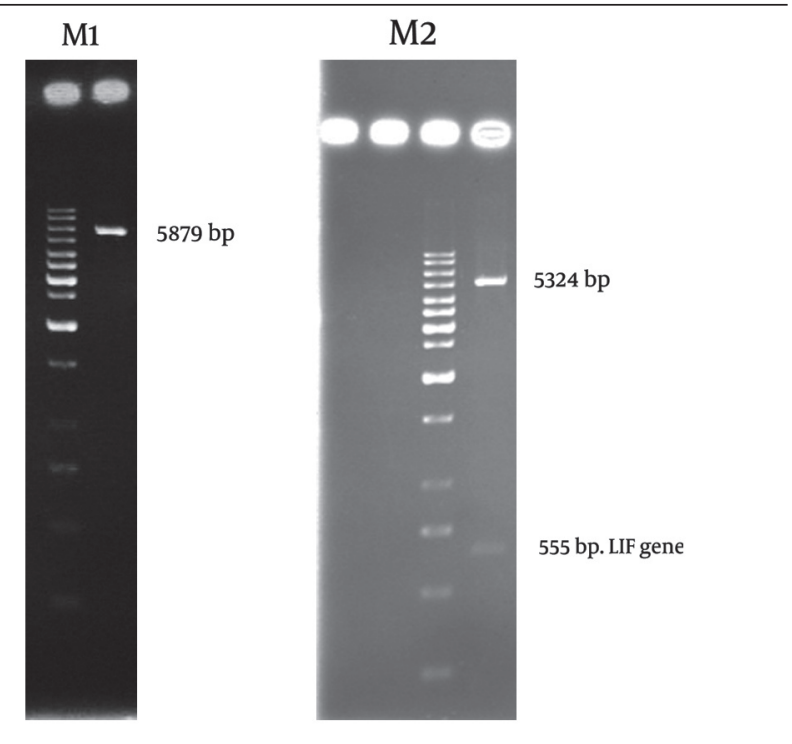

First and second plasmid digestion is shown after digestion with BamHI (left) and subsequent cutting with XbaI (right); M, GeneRuler ${ }^{\mathrm{TM}} 1 \mathrm{~kb}$ ladder (Fermentas SM0311), lane 1, the First digestion and lane 2, the second digestion results.

collected from 2 to $14 \mathrm{~h}$ after induction with different concentrations of the inducer IPTG. SDS-PAGE analysis clearly indicates the expression of the 19.7 kDa LIF (Figure 5). Before induction, the expression of LIF cDNA was very low, but after induction with IPTG, the level of expression was increased. Objective differences were not observed between the two different concentrations of inducer. But the maximum expression was indicated at 12 hour 


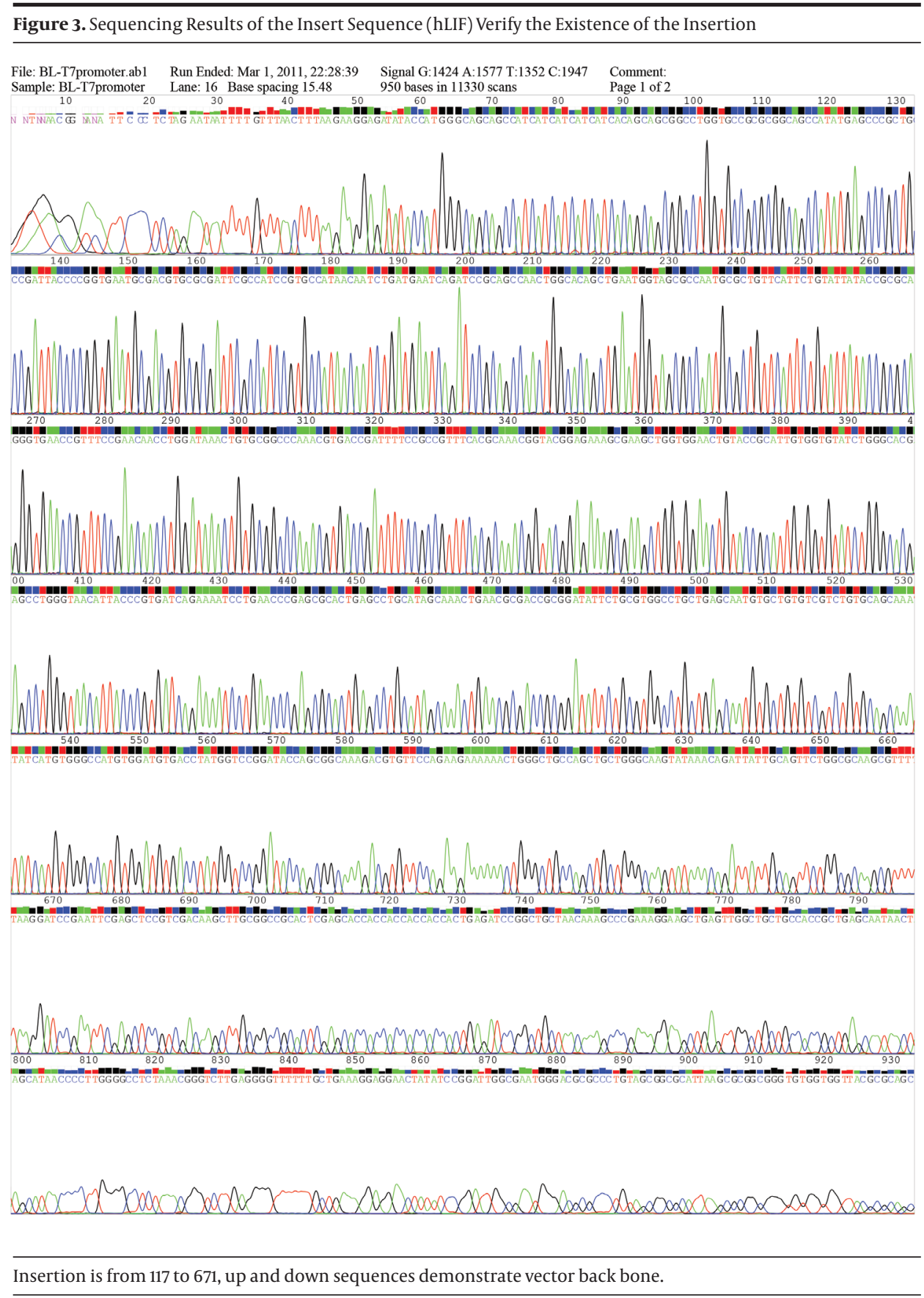

after initial induction. Afterward, to detect the optimum temperature expression of this recombinant protein, induction was performed at three different temperatures and the best result was observed at $22^{\circ} \mathrm{C}$ (Figure 6).Two cultures were collected from 2 to $14 \mathrm{~h}$ after induction to determine the time of maximum expression level. Before induction, the expression of LIF cDNA was very low, but after induction with IPTG, the level of expression was increased. Objective differences were not observed between the two different concentrations of inducer. But the maximum expression was indicated at 12 hour after initial induction. Afterward, to detect the optimum temperature expression of this foreign protein, induction was performed at three different temperatures and the best result was observed at $22^{\circ} \mathrm{C}$ (Figure 6).

Western blot analysis was certainly confirmed that the 
Figure 4. The Blast Result of Optimized LIF sequence, This Optimized Sequence Showed 79\% Identity with Human Leukemia Inhibitory Factor

\begin{tabular}{|c|c|c|c|}
\hline \multicolumn{4}{|c|}{$\begin{array}{l}\text { Score }=475 \text { bits }(526), \quad \text { Expect }=3 e-130 \\
\text { Identities }=431 / 543(79 \%), \text { Gaps }=0 / 543 \text { (0s) } \\
\text { Strand=Plus/Plus }\end{array}$} \\
\hline Query & 122 & 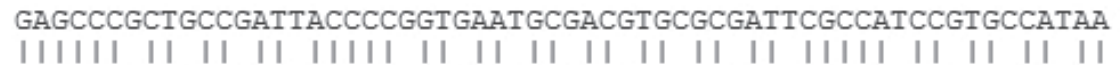 & 181 \\
\hline Sbjct & 114 & GAGCCCCCTCCCCATCACCCCTGTCAACGCCACCTGTGCCATACGCCACCCATGTCACAA & 173 \\
\hline Query & 182 & CAATCTGATGAATCAGATCCGCAGCCAACTGGCACAGCTGAATGGTAGCGCCAATGCGCT & 241 \\
\hline Sbjct & 174 & CAÄCCTCATGAACCAGATCAGGAGCCAACTGGCACAGCTCAATGGCAGTGCCAATGCCCT & 233 \\
\hline Query & 242 & 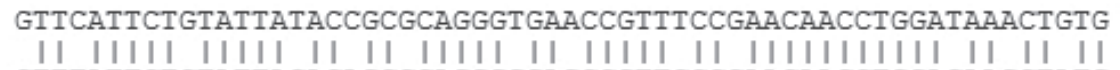 & 301 \\
\hline Sbjet & 234 & СTTTATTCTCTATTACACAGCCCAGGGGGAGCCGTTCCCCAACAACCTGGACAAGCTATG & 293 \\
\hline Query & 302 & 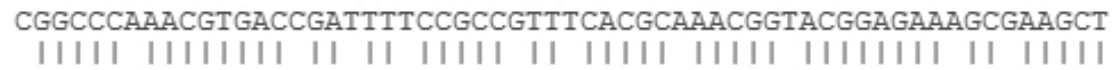 & 361 \\
\hline Sbjet & 294 & TGGCCCCAACGTGACGGACTTCCCGCCCTTCCACGCCAACGGCACGGAGAAGGCCAAGCT & 353 \\
\hline Query & 362 & GGTGGAACTGTACCGCATTGTGGTGTATCTGGGCACGAGCCTGGGTAACATTACCCGTGA & 421 \\
\hline Sbjct & 354 & GGTGGAGCTGTACCGCATAGTCGTGTACCTTGGCACCTCCCTGGGCAACATCACCCGGGA & 413 \\
\hline Query & 422 & $\begin{array}{l}\text { TCAGAAAATCCTGAACCCGAGCGCACTGAGCCTGCATAGCAAACTGAACGCGACCGCGGA } \\
|||||||||||||||||||||||||||||||||||||||||||||||l| l \mid\end{array}$ & 481 \\
\hline Sbjet & 414 & CCAGAAGATCCTCAACCCCAGTGCCCTCAGCCTCCACAGCAAGCTCAACGCCACCGCCGA & 473 \\
\hline Query & 482 & 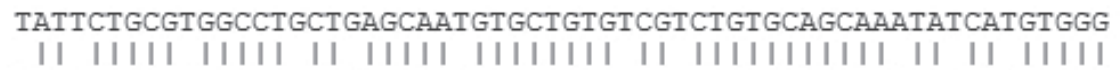 & 541 \\
\hline Sbjet & 474 & CATCCTGCGAGGCCTCCTTAGCAACGTGCTGTGCCGCCTGTGCAGCAAGTACCACGTGGG & 533 \\
\hline Query & 542 & 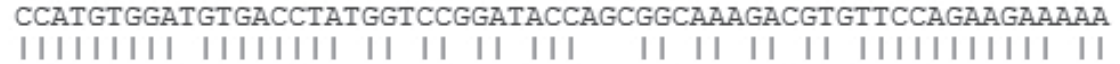 & 601 \\
\hline Sbjct & 534 & CCATGTGGACGTGACCTACGGCCCTGACACCTCGGGTAAGGATGTCTTCCAGAAGAAGAA & 593 \\
\hline Query & 602 & $\begin{array}{l}\text { ACTGGGCTGCCAGCTGCTGGGCAAGTATAAACAGATTATTGCAGTTCTGGCGCAAGCGTT } \\
|||||||||||||||||||||||||||||||||||||||||| l||\end{array}$ & 661 \\
\hline Sbjet & 594 & GCTGGGCTGTCAACTCCTGGGGAAGTATAAGCAGATCATCGCCGTGTTGGCCCAGGCCTT & 653 \\
\hline Query & 662 & $\begin{array}{c}\text { TTA } \\
\text { || }\end{array}$ & \\
\hline Sbjct & 654 & CTA & \\
\hline
\end{tabular}

Figure 5. The SDS-PAGE (12\%) Gel Shows the hLIF Recombinant Protein With the Expected Molecular Size of $19.7 \mathrm{kDa}$

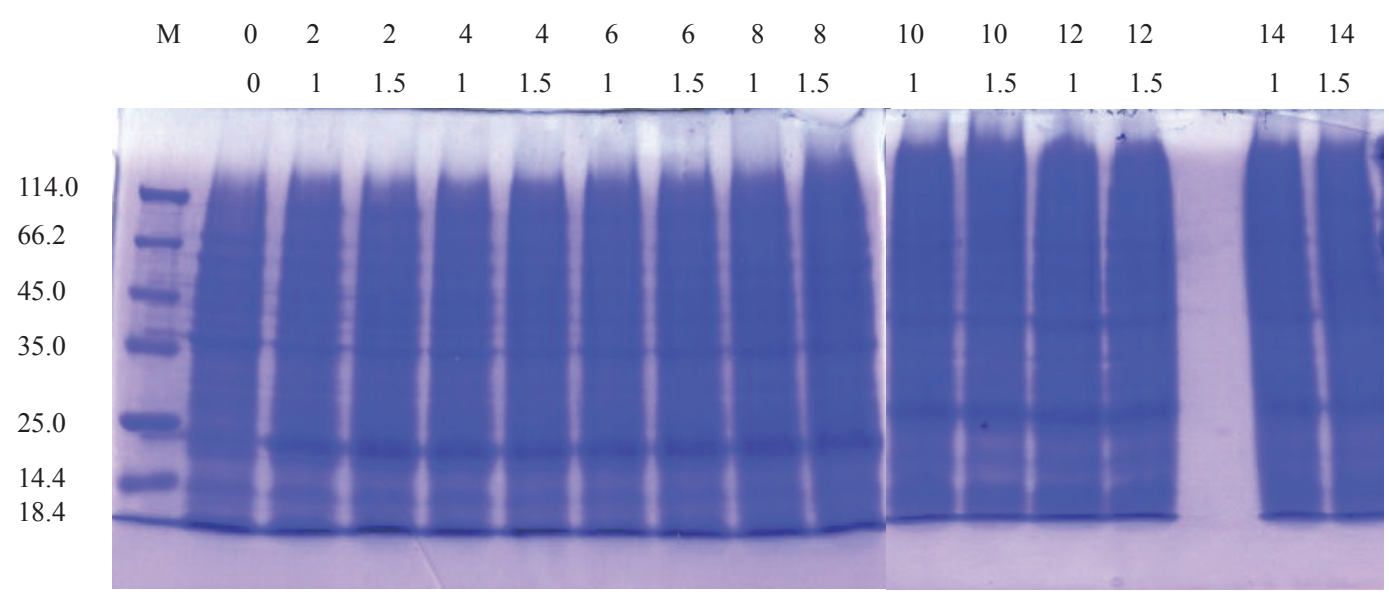

Abbreviations: $\mathrm{C}$, concentration of IPTG; $\mathrm{h}$, time after induction a) protein molecular weight marker bands (Fermentas SM0431); b) M, protein molecular weight marker 


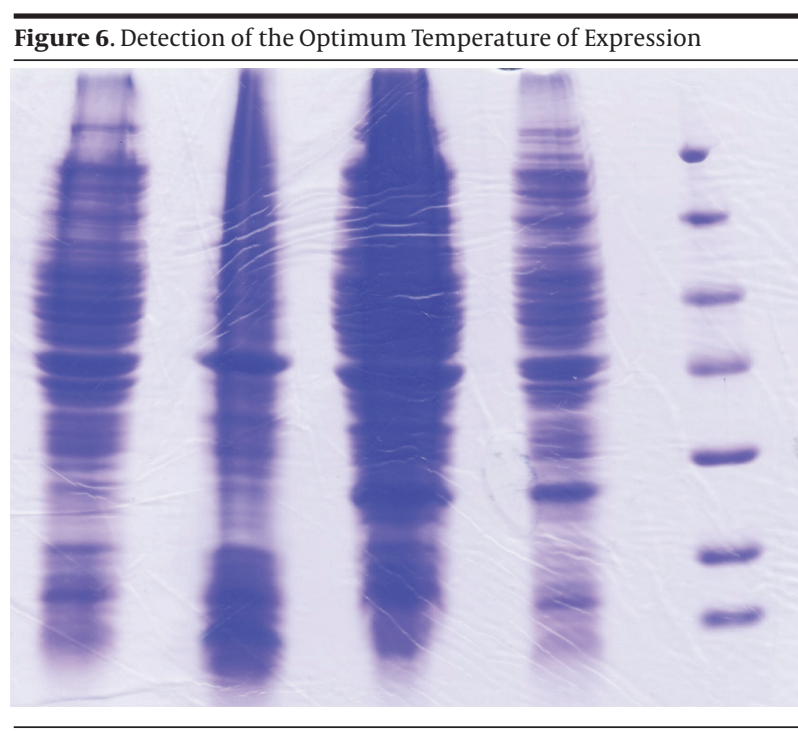

Lane $\mathrm{M}$, protein molecular weight marker; Lane 1, induction at $28^{\circ} \mathrm{C}$; Lane 2 , induction at $22^{\circ} \mathrm{C}$; Lane 3 , induction at $37^{\circ} \mathrm{C}$; Lane 4 , negative control (Lysates of bacterial cells without insert).

\section{Figure 7. Western Blot Analysis}

1

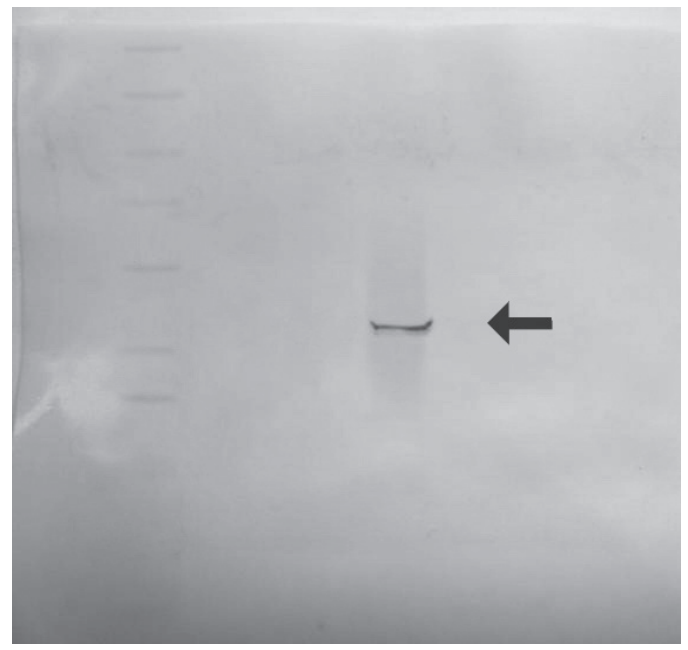

Lane 1, protein molecular weight marker; Lane 2, Transformed E. coli expressing hLIF protein; Lane 3: negative control. The arrow shows desired protein band.

band which observed in SDS-PAGE is the desired protein (Figure 7). Western blot analysis was certainly confirmed that the band which observed in SDS-PAGE is the desired protein (Figure 7).

\section{Discussion}

Because of the degeneracy of the genetic code, all amino acids, except methionine and tryptophan, are encoded by more than one codon and many codons are synonymous for the same amino acid (29). Nevertheless, some synonymous codons are more abundant than others. Alignment of genomic DNA from different species showed that wobble codons are used differently in bacteria, mitochondria and nuclear eukaryotic (30-32). This relative difference in the frequency of event for each codon is called codon bias. The codon usage table for a species Homo sapiens and E. coli gives the codon bias information for that species (27). To date, the heterologous gene expression is applied as a fundamental methodology in biological process with some restrictions in implementation (33). For instance, the difference and frequency of used codons might extremely decreased the expression by poorly translated mRNAs, decreased mRNA stability (31, 32), which could cause incorrect extension of amino acid chain (30). A potential solution for the codon bias is to optimize the codon sequences of a gene to adapt the conditions of the host without modifying the original amino acid sequence of the protein. To validate if a gene needs to be optimized, it must be pre checked using Rare Codon Analysis Tools. These tools compute three aspects of gene sequence. First is the Codon Adaptation Index (CAI); It is the distribution of codon usage frequency along the length of a CDS to be expressed in the favorite target host organism. Possibility of high protein expression level is correlated to the value of CAI. A CAI of 1.0 is considered as ideal, while a CAI of more than 0.8 is rated as good for expression in the desired expression organism. The lower the number, the higher is the chance that the gene would be expressed poorly. Codon optimization tool can typically improve a sequence to reach a CAI of higher than 0.8 , thus results in better chance of high level protein expression $(34,35)$. Second is the GC content of desired gene. The ideal percentage range of GC content is between 30\% and $70 \%$. Any value outside of this range would adversely affect transcriptional and translational efficiency (36). Third is the Codon Frequency Distribution (CFD); the percentage distribution of codons in computed codon quality groups. Codons with values lower than 30 are likely to hamper the expression efficiency (Gen Script's Optimum Gene TM). After analysis of the sequence of LIF CDS, its codon was optimized with reference to E. coli as it is a popular host for heterologous gene expression. CAI value of LIF was estimated 0.64 which is outside of the optimum range, the Average GC content was 59.34 and its Codon Frequency Distribution (CFD) in E. coli was estimated as $14 \%$. This unoptimized gene employs tandem rare codons which can reduce the efficiency of translation or even separate the translational machinery. In $E$. coli the heterologous protein production efficiency was increased by using production of synthetic genes and because of the goal of a cloning process is the maximum expression of the target gene, thus the researchers must assemble the entire best situation for the highest expres- 
sion of target gene. Therefore the LIF CDS was optimized and synthesized to reach the best quality and quantity in production.

\section{Acknowledgments}

We thank the deputy Research of Jundishapur University of Medical Science of Ahvaz for supporting this work.

\section{Authors' Contribution}

Hamid Galehdari and the authors have conducted the study.

\section{Financial Disclosure}

None declared.

\section{Funding/ Support}

This work was supported by deputy research of Jundishapur University of Medical Science of Ahvaz.

\section{References}

1. Tjenlund A. Leukemia inhibitor factor (LIF) and gp130 in early defence against HIV-1 infection. Stockholm; 2006.

2. Dimitriadis E, Salamonsen LA, Menkhorst E. Leukemia Inhibitory Factor and Human Endometrial Receptivity. Indian J Physiol Pharmacol. 2010;54(5):17-26.

3. Dillon SR, Sprecher C, Hammond A, Bilsborough J, RosenfeldFranklin M, Presnell SR, et al. Interleukin 31, a cytokine produced by activated $\mathrm{T}$ cells, induces dermatitis in mice. Nat Immunol. 2004;5(7):752-60.

4. Pflanz S, Hibbert L, Mattson J, Rosales R, Vaisberg E, Bazan JF, et al. WSX-1 and glycoprotein 130 constitute a signal-transducing receptor for IL-27. J Immunol. 2004;172(4):2225-31.

5. Genovese MC, McKay JD, Nasonov EL, Mysler EF, da Silva NA, Alecock E, et al. Interleukin-6 receptor inhibition with tocilizumab reduces disease activity in rheumatoid arthritis with inadequate response to disease-modifying antirheumatic drugs: the tocilizumab in combination with traditional disease-modifying antirheumatic drug therapy study. Arthritis Rheum. 2008;58(10):296880

6. Gearing DP, Comeau MR, Friend DJ, Gimpel SD, Thut CJ, McGourty J, et al. The IL-6 signal transducer, gp130: an oncostatin $\mathrm{M}$ receptor and affinity converter for the LIF receptor. Science. 1992;255(5050):1434-7.

7. Kurek J. AM424: history of a novel drug candidate. Clin Exp Pharmacol Physiol. 2000;27(7):553-7.

8. Hilton DJ, Nicola NA, Metcalf D. Distribution and binding properties of receptors for leukaemia inhibitory factor. Ciba Found Symp. 1992;167:227-39; discussion 39-44.

9. Rolfe BE, Stamatiou S, World CJ, Brown L, Thomas AC, Bingley JA, et al. Leukaemia inhibitory factor retards the progression of atherosclerosis. Cardiovasc Res. 2003;58(1):222-30.

10. Cavaletti G, Marmiroli P. The role of growth factors in the prevention and treatment of chemotherapy-induced peripheral neurotoxicity. Curr Drug Saf. 2006;1(1):35-42.

11. Trouillas M, Saucourt C, Guillotin B, Gauthereau X, Taupin JL, Moreau JF, et al. The LIF cytokine: towards adulthood. Eur Cytokine Netw. 2009;20(2):51-62.

12. Okita K, Yamanaka S. Intracellular signaling pathways regulating pluripotency of embryonic stem cells. Curr Stem Cell Res Ther. 2006;1(1):103-11.

13. Heinrich PC, Behrmann I, Muller-Newen G, Schaper F, Graeve L.
Interleukin-6-type cytokine signalling through the gp130/Jak/ STAT pathway. Biochem J.1998;334 (Pt 2):297-314.

14. Wobus AM, Boheler KR. Embryonic stem cells: prospects for developmental biology and cell therapy. Physiol Rev. 2005;85(2):63578.

15. Fakher R, Saki G. assessment of Motility survival Rate of Asthenospermic Men's Sperm Cultured in Media Pluse Leukemia Inhibitor Factor. Int J Pharmacol. 2010;6(3):306-10.

16. Metcalf D, Nicola NA, Gearing DP. Effects of injected leukemia inhibitory factor on hematopoietic and other tissues in mice. Blood.1990;76(1):50-6.

17. Mayer P, Geissler K, Ward M, Metcalf D. Recombinant human leukemia inhibitory factor induces acute phase proteins and raises the blood platelet counts in nonhuman primates. Blood. 1993;81(12):3226-33.

18. Cheema SS, Richards L, Murphy M, Bartlett PF. Leukemia inhibitory factor prevents the death of axotomised sensory neurons in the dorsal root ganglia of the neonatal rat. $J$ Neurosci Res. 1994;37(2):213-8

19. Cheema SS, Richards LJ, Murphy M, Bartlett PF. Leukaemia inhibitory factor rescues motoneurones from axotomy-induced cell death. Neuroreport. 1994;5(8):989-92.

20. Kurek JB, Austin L, Cheema SS, Bartlett PF, Murphy M. Up-regulation of leukaemia inhibitory factor and interleukin-6 in transected sciatic nerve and muscle following denervation. Neuromuscul Disord.1996;6(2):105-14.

21. Ikeda K, Iwasaki Y, Tagaya N, Shiojima T, Kinoshita M. Neuroprotective effect of cholinergic differentiation factor/leukemia inhibitory factor on wobbler murine motor neuron disease. Muscle Nerve. 1995;18(11):1344-7.

22. Hilton DJ, Gough NM. Leukemia inhibitory factor: a biological perspective. J Cell Biochem. 1991;46(1):21-6.

23. Hilton DJ. LIF: lots of interesting functions. Trends Biochem Sci. 1992;17(2):72-6.

24. Mikolajczyk M, Skrzypczak J, Szymanowski K, Wirstlein P. The assessment of LIF in uterine flushing--a possible new diagnostic tool in states of impaired fertility. Reprod Biol.2003;3(3):259-70.

25. Richter KS. The importance of growth factors for preimplantation embryo development and in-vitro culture. Curr Opin Obstet Gynecol.2008;20(3):292-304.

26. Dimitriadis E, Menkhorst E, Salamonsen LA, Paiva P. Review: LIF and IL11 in trophoblast-endometrial interactions during the establishment of pregnancy. Placenta. 2010;31 Suppl:S99-104.

27. Comeron JM, Aguade M. An evaluation of measures of synonymous codon usage bias. J Mol Evol.1998;47(3):268-74

28. Sambrook J, Russell DW. Molecular Cloning a laboratory manual. New York: Cold Spring Harbor Laboratory Press; 2001.

29. Ikemura T. Codon usage and tRNA content in unicellular and multicellular organisms. Mol Biol Evol.1985;2(1):13-34.

30. Calderone TL, Stevens RD, Oas TG. High-level misincorporation of lysine for arginine at AGA codons in a fusion protein expressed in Escherichia coli.J Mol Biol.1996;262(4):407-12.

31. Goldman E, Rosenberg AH, Zubay G, Studier FW. Consecutive low-usage leucine codons block translation only when near the 5' end of a message in Escherichia coli.J Mol Biol.1995;245(5):46773.

32. Sorensen MA, Kurland CG, Pedersen S. Codon usage determines translation rate in Escherichia coli. J Mol Biol.1989;207(2):365-77.

33. Gustafsson C, Govindarajan S, Minshull J. Codon bias and heterologous protein expression. Trends Biotechnol. 2004;22(7):346-53.

34. Sharp PM, Li WH. The codon Adaptation Index--a measure of directional synonymous codon usage bias, and its potential applications. Nucleic Acids Res. 1987;15(3):1281-95.

35. Carbone A, Zinovyev A, Kepes F. Codon adaptation index as a measure of dominating codon bias. Bioinformatics. 2003;19(16):200515.

36. Puigbo P, Guzman E, Romeu A, Garcia-Vallve S. OPTIMIZER: a web server for optimizing the codon usage of DNA sequences. Nucleic Acids Res. 2007;35(Web Server issue):W126-31. 